\title{
PERAN MEDIA TEKNOLOGI PENDIDIKAN PADA KEGIATAN BELAJAR MENGAJAR DI TENGAH PANDEMIK COVID-19
}

\author{
Zaharah \\ zaharah@uinjkt.ac.id. \\ (Universitas Islam Negeri Syarif Hidayatullah, Jakarta,dan Universitas \\ Muhammadiyah,Tangerang) \\ Ibnu Sina \\ Ibnu.sina19@gmail.com \\ (Universitas Pamulang Tangerang).
}

\begin{abstract}
Abstrack
Saat ini masyarakat dunia digemparkan oleh terjadinya wabah Coronavirus yang berasal dari kota Wuhan, China yang terjadi di bulan November 2019 tahun lalu. Corona virus ini sangat berbahaya karena sampai saat ini belum ditemukan obat atau vaksin penanggulangannya. Artikel ini bertujuan untuk menjelaskan bagaimana peran teknologi pendidikan pada aktivitas kegiatan belajar mengajar selama masa karantina akibat dari virus corona ini yang selama ini proses belajar mengajar diadakan di sekolah atau kelas dengan mengunakan keterbatasan media teknologi tetapi dengan adanya pendemi covid-19, KBM dipindahkan di rumah secara E-Learning dengan mengunakan beberapa aplikasi dan berbagai alat technologi, pengajaran seperti smartphone, komputer dan notebook. Dampak yang disebabkan oleh virus corona ini menyangkut semua aspek dalam kehidupan masyarakat. Kajian ini dilakukan melalui studi pustaka dengan melihat hasil-hasil survei dan studi literatur, journal dan document beberapa media cetak maupun elektronik serta buku yang berhubungan dengan pengajaran dan sosial masyrakat, sosiologi dan antropologi. Kesimpulan dari tulisan ini menunjukkan adanya langkah pemerintah mengeluarkan kebijakan kepada masyarakat untuk tidak beraktivitas apapun diluar rumah, semua pekerjaan dilaksanakan dari rumah, termasuk kegiatan belajar dan mengajar (KBM.
\end{abstract}

\section{Keyword: Peran, Media teknologi, Kbm, pandemic Covid 19.}

\begin{abstract}
Abstrack
Currently the world community is shocked by the Coronavirus outbreak originating from the city of Wuhan, China that occurred in November 2019 last year. Corona virus is very dangerous because until now no drug or vaccine was found. This article aims to explain how the role of educational technology in teaching and learning activities during quarantine due to this corona virus which during the teaching and learning process is held in schools or classrooms using the limitations of technological media but with 19 co-pesticides, KBM moved from home in E-Learning with using several applications and various technological tools, teaching such as smartphones, computers and notebooks. The impact caused by the corona virus concerns all aspects of human life. This research was conducted through a literature study by looking at survey results and literature studies, journals and documents from several print and electronic media as well as books relating to teaching and social society, sociology and anthropology. The conclusion of this paper shows the government's step in issuing a large-scale social designation policy (PSBB) to the public not to carry out
\end{abstract}




\section{Peran Media Teknologi Pendidikan Pada Kegiatan Belajar Mengajar Di}

\section{Tengah Pandemik Covid-19}

activities outside the home, all work is done from home, including teaching and learning activities (KBM).

\section{Keyword: Media technology, Kbm, pandemic Covid 1Pendahuluan}

\section{A. Pendahuluan}

Awal tahun 2020 kita dikejutkan oleh Virus baru yang dinamakan Virus Corona atau istilahnya dengan sebutan (Covid-19) virus yang menyerang sistem pernapasan manusia, yang pada awalnya melanda negeri China, yang ditemukan pada November 2019 tepatnya di kota Wuhan. Virus corona awalnya virus ini dianggap seperti virus biasa saja yang datang dan pergi, ternyata prediksi yang salah, rupanya virus ini adalah virus yang lain dari pada yang lain yang dapat mematikan manusia dan penyebarannya sangat cepat, dengan gejala yang menyerupai filek, flu, mulai batuk, demam dan gangguan tenggorokan atau hidung meler. Sampai saat ini belum diketahui penyebab dari virus Corona, tetapi diketahui virus ini disebarkan oleh hewan dan mampu menjangkit dari satu spesies ke spesies lainnya, termasuk manusia ${ }^{1}$.

Kejadian ini semakin hari semakin merebak di masyarakat Wuhan, banyak korban berjatuhan. Bahkan bukan hanya di masyarakat Wuhan, tetapi sudah merebak ke provinsi lainya di Cina. Keadaan ini sangat terpukul bagi negara China yang banyak mengalami kerugian secara ekonomi, selain menghentikan semua aktivitas yang biasanya berjalan kondusif. Virus ini sangat luar biasa, hanya dalam 3 bulan terakhir virus ini sudah memakan korban ribuan jiwa, bahkan saat ini bukan hanya di China saja yang tertinggi tingkat wabahnya, tetapi sudah menyusul negaranegara lain seperti Italia, Iran, dan Korea Selatan, dan menyusul negara-negara yang

http://www.kompasiana.com/recordwiputraanggara/ 5e93d3b709713.h. lain, seperti Indonesia, Inggris, Jepang, Amerika Serikat, Jerman dan negaranegara lainnya.

Di Indonesia, pemerintah mengeluarkan dan memberikan beberapa kebijakan terkait wabah Covid-19 ini. Salah satunya yaitu larangan masyarakat berkumpul dan melakukan aktivitas di luar rumah, dan menganjurkan untuk tinggal di rumah "Stay at Home", beribadah di rumah, bekerja dari rumah, belajar dari rumah." Hal ini disebabkan karena virus ini dapat berjangkit melalui kontak fisik, yaitu sentuhan, udara dan airborne dan harus menjaga jarak sosial (physical distancing) kurang lebih 1,5 meter.

Salah satu instruksi pemerintah tentang kegiatan atau melakukan aktivitas di rumah adalah kegiatan pembelajaran. Pembelajaran tidak boleh berhenti walaupun pemerintah menginstruksikan libur selama 14 hari untuk sekolah dan kampus yang berada di Indonesia. Kegiatan Belajar mengajar (KBM) dipindahkan di rumah, tetapi tetap harus dikontrol oleh guru ataupun dosen serta orang tua, dengan menggunakan pembelajaran jarak jauh. Pembelajaran Jarak jauh ini dilaksanakan selama kurang lebih 14 hari, tetapi tidak menutup kemungkinan akan ditambah lagi karena melihat situasi dan kondisi dari perkembang Covid-19 ini.

\section{B. Metode Penelitian}

Penelitian ini menggunakan metode kualitatif dengan studi literatur (dokumen) dari beberapa sumber baik media cetak maupun elektronik, serta buku maupun ejournal. Penelusuran jurnal dilakukan melalui Google Scholar. Berdasarkan hasil penelusuran diperoleh dan dipilih data 


\section{Peran Media Teknologi Pendidikan Pada Kegiatan Belajar Mengajar Di Tengah Pandemik Covid-19}

yang memenuhi kriteria. Analisis kajian literatur meliputi pengumpulan data, reduksi data, penyajian data, dan penarikan kesimpulan.

\section{Pembahasan}

Belajar adalah perubahan dalam tingkah laku ${ }^{2}$, yaitu proses perubahan perilaku secara aktif, proses mereaksi terhadap semua situasi yang ada di sekitar individu, proses yang diarahkan pada suatu tujuan, proses berbuat melalui berbagai pengalaman, proses melihat, mengamati, dan memahami sesuatu yang dipelajari. Pembelajaran adalah proses interaksi peserta didik dengan pendidik dan sumber belajar pada suatu lingkungan belajar. Pembelajaran merupakan bantuan yang diberikan pendidik agar dapat terjadi proses pemerolehan ilmu dan pengetahuan, penguasaan kemahiran dan tabiat, serta pembentukan sikap dan kepercayaan pada peserta didik. Dengan kata lain, pembelajaran adalah proses untuk membantu peserta didik agar dapat belajar dengan baik. Dan juga belajar merupakan suatu proses usaha sadar yang dilakukan oleh individu untuk suatu perubahan dari tidak tahu menjadi tahu, dari tidak memiliki sikap menjadi bersikap benar, dari tidak terampil menjadi terampil melakukan sesuatu. Belajar tidak hanya sekedar memetakan pengetahuan atau informasi yang disampaikan. Namun bagaimana melibatkan individu secara aktif membuat atau pun merevisi hasil belajar yang diterimanya menjadi suatu pengalamaan yang bermanfaat bagi pribadinya. $^{3}$

\footnotetext{
${ }^{2}$ M. Ngalim P.1997.Psikologi Pendidikan. Bandung. Penerbit. Remaja Rosda Karya. ISBN 979-514-036-1. Edisi pertama. cetakan ke. XXVII.hlm.20.

${ }^{3}$ D. Hardianto. 2005. Media Pendidikan sebagai sarana pembelajaran efektif, Jakarta. hlm.6
}

Proses pembelajaran yang dialami sepanjang hayat seorang manusia dapat berlaku di manapun dan kapanpun. Pembelajaran mempunyai pengertian yang mirip dengan pengajaran, walaupun mempunyai konotasi yang berbeda. Dalam konteks pendidikan, guru mengajar supaya peserta didik dapat belajar dan menguasai isi pelajaran hingga mencapai sesuatu objektif yang ditentukan (aspek kognitif), juga dapat mempengaruhi perubahan sikap (aspek afektif), serta keterampilan (aspek psikomotor) seseorang peserta didik. Pengajaran memberi kesan hanya sebagai pekerjaan satu pihak, yaitu pekerjaan guru saja. Sedangkan pembelajaran juga menyiratkan adanya interaksi antara guru dengan peserta didik.

Kalau kita melihat dan merasakan pembelajaran saat ini, intraksi antara murid dengan guru memang terjadi tetapi lewat dunia maya/virtual, atau interaksi terjadi dengan mengunakan alat bantu atau perangkat teknologi berupa komputer, notebook, dan handphone. Ia dapat juga dengan menggunakan aplikasi pembelajaran jarak jauh yang saat ini disediakan oleh pemerintah secara gratis ataupun berbayar kalau yang menyediakan pihak swasta. Distance learning atau disebut dengan pembelajaran jarak jauh saat ini sangat dibutuhkan oleh seluruh anak didik mulai dari tingkat sekolah dasar sampai perguruan tinggi, dan ini bukan hanya terjadi di Indonesia saja bahkan hampir seluruh dunia melaksanakan pembelajaran secara E-learning. Situasi dan kondisi bisa saja sedang tidak kondusif, tetapi aktivitas dan belajar harus bisa dapat dilaksanakan dimana saja. Apalagi sekarang banyak ketersedian peralatan teknologi yang dapat mendukung aktivitas seluruh manusia melakukan apa saja dan kapan saja, dimana saja. Sehingga tidak ada lagi dibatasi oleh waktu dan tempat. 


\section{Peran Media Teknologi Pendidikan Pada Kegiatan Belajar Mengajar Di Tengah Pandemik Covid-19}

Pengajaran dapat diartikan dengan perbuatan belajar oleh siswa dan mengajar oleh guru. Kedua komponen ini tidak dapat dipisahkan dalam proses kegiatan belajar mengajar (KBM). Kegiatan belajar mengajar adalah satu kesatuan dari dua kegiatan yang searah. Kegiatan belajar adalah kegiatan primer, sedangkan mengajar adalah kegiatan sekunder yang dimaksudkan agar terjadi kegiatan secara optimal.

Dapat ditarik kesimpulan bahwa Pembelajaran adalah usaha sadar dari guru untuk membuat siswa belajar, yaitu terjadinya perubahan tingkah laku atau prilaku pada diri siswa yang belajar, dimana perubahan itu didapatkan dengan kemampuan baru yang berlaku dalam waktu yang relatif lama. Tetapi dengan keadaan sekarang, apakah pembelajaran dengan mengunakan pelajaran jarak jauh dapat dikatakan pembelajaran dilaksanakan secara optimal? Dan ada tidak perubahan perilaku terhadap peserta didik atau siswa setelah mengikuti kegiatan pembelajaran secara jarak jauh? dan bagaimana hasil pembelajaran yang dicapai oleh siswa setelah mengikuti pembelajaran jarak jauh? ini yang perlu dikaji dan diulas dalam artikel ini. Setelah mengamati dan menganalisis dalam beberapa minggu pembelajaran yang dilaksanakan serang online oleh siswa, mahasiswa atau pun guru sebagai control banyak ditemukan hal- hal yang positif walupun ini mungkin tidak cukup valid untuk diambil suatu kesimpulan karena waktu yang sangat singkat.

Pelaksanaan pembelajaran secara elearning ini juga yang dimaksud oleh kementerian kemendikbud dengan penerapan pembelajaran secara mandiri yang sebelum terjadi pandemic Covid-19 digaungkan oleh Nadiem Makarim dengan sebutan merdeka belajar. Siswa dituntut harus melek teknologi, harus berkreasi, punya memiliki motivasi yang tinggi, mampu membuat suatu inovasi yang tujuannya untuk mempersiapkan kaum milineal di masa depan siap dengan tantangan globalisasi.

Angan-angan Nadiem Makarim saat ini terealisasi dengan adanya siswa dan mahasiwa yang hampir $65 \%$ dapat menggunakan atau melaksanakan pembelajaran secara Virtual/Dictance Learning. Walaupun persentase siswa pengguna Online Learning belum begitu signifikan, tetapi setidaknya sudah menunjukkan adanya suatu kemajuan, perkembangan, dan inovasi dalam sistem pendidikan di Indonesia dengan menggunakan Online Learning ini. Memang sebelumnya banyak juga sekolahsekolah dan universitas yang mengunakan e-learning atau Online learning, tetapi tidak seluruhnya dapat menggunakan online learning ini, dikarenakan keterbatasan sumber daya seperti guruguru yang belum mengerti dan paham dengan berbagai aplikasi online learning yang digunakan dalam proses dan kegiatan belajar mengajar di sekolah. Selain keterbatasan jaringan internet, ketersedian smarphone atau notebook yang tidak semua siswa dapat memilikinya.

Pelaksanaan jarak jauh sebenarnya menjadi salah satu aplikasi dari pembelajaran Merdeka yang dicanangkan oleh Kemendikbud, karena belajar merdeka tidak mengejar target yang dipaksakan, belajar itu butuh waktu dan proses. Atas nama pendidikan tidak pernah berkurang dari berbagai inovasi, seperti pembelajaran yang sedang dialami oleh anak didik kita dengan menggunakan system online. Semua peserta didik butuh hal yang berbeda dari guru, seperti yang sekarang dialami oleh siswa-siswa yang sebelumnya hanya mengikuti daring, apabila ada pekerjaan rumah yang tidak cukup waktu dilaksanakan di sekolah. Namun inovasi pembelajaran seperti itu akhirnya harus atau terpaksa dilakukan 


\section{Peran Media Teknologi Pendidikan Pada Kegiatan Belajar Mengajar Di Tengah Pandemik Covid-19}

oleh murid-murid, karena keadaan dan sebab atau dampak dari Covid - 19 .

Belajar Merdeka bukan proses yang diberikan, akan tetapi proses yang digerakkan. Bagaimana mampu bergerak dengan kemauan untuk mencapai tujuan dan konsisten yang menjadi prioritas utama. Reformasi pendidikan sangat sulit untuk dilakukan, disamping membutuhkan waktu yang lama juga membutuhkan kebijakan pemangku kepentingan. Belajar merdeka adalah belajar alamiah dari proses yang dialami secara merdeka di luar bangku sekolah, seperti di rumah. Pelaksanaan Kegiatan belajar mengajar yang saat ini dilaksanakan dengan menggunakan aplikasi pembelajaran jarak jauh atau learning memang belum mencapai hasil yang maksimal. Penulis belum bisa menjelaskan secara detail karena belum mendapatkan hasil evaluasi dari dinas pendidikan yang terkait dan guru-guru yang melaksanakan pembelajaran jarak jauh. Tetapi secara acak dan random penulis dapat menyimpulkan secara keseluruhan pelaksanaan pembelajaran jarak jauh sudah sangat signifikan, karena adanya control dari orang tua dan monitor jarak jauh dari para guru. Kegiatan pembelajaran melalui online Learning pada masa diberlakukan belajar di rumah hari pertama, tidak dipungkiri banyak menimbulkan kendala bagi yang belum pernah melakukannya. Ini menurut pengamatan dan analisis di sebagian sekolah, karena keterbatasan alat/media handphone yang terhubung ke internet, dan kurangnya koneksi internet yang secara bersamaan harus menggunakan jaringan internet yang begitu besar. Di Jakarta hampir 95\% sekolah menggunakan online learning, ${ }^{4}$ dan pastinya terjadi kalang kabut guru, murid dan orang tua untuk menyiapkan semua itu, karena tentu saja endemic dari Covid-
19 ini tidak diduga begitu cepat penyebaranya, sehingga pemerintah dan masyarakat belum begitu siap dalam menghadapinya, dan pemerintah harus cepat mengambil tindakan pencegahan agar tidak lebih banyak lagi korban yang terkena virus corona ini, karenanya wabah ini dianggap menjadi bencana Nasional, bahkan bencana di seluruh dunia.

Penerapan kebijakan belajar dan kuliah online yang ditetapkan oleh kementerian pendidikan dan kebudayaan sebagai bentuk kewaspadaan dan pencegahan penyebaran wabah corona Virus (Covid-19) yang semakin hari semakin meluas di Indonesia. Sebagai bentuk kewaspadaan dan pencegahan semua kegiatan pembelajaran dilaksanakan melalui pembelajaran jarak jauh dalam bentuk perkuliahan secara online, perkuliahan model daring ataupun dalam bentuk penugasan di rumah. ${ }^{5}$ Tidak hanya kegiatan belajar mengajar saja yang turut terganggu, virus yang berasal dari negeri tirai bambu itu juga menyebabkan pelaksanaan kegiatan di sekolah dan kampus yang semula telah diagendakan jadi berubah tidak sesuai dengan rencana yang telah dijadwalkan. Para Murid, Dosen dan organisasi kemahasiswaan dilarang untuk melakukan kegiatan yang melibatkan orang banyak selama 14 hari. Namun, seluruh tenaga pendidik dan tenaga kependidikan tetap harus hadir bekerja di kampus seperti biasa. Langkah ini diambil untuk mengantisipasi dan melakukan pencegahan penyebaran coronavirus di wilayah sekolah, kampus dan sekitarnya.

Berita keganasan Covid-19 membuat masyarakat merasa was-was karena adanya pemberitaan yang sangat gencar dilakukan oleh media televisi dan media electronic.

\footnotetext{
${ }^{5}$ Media online,Alinea.id/nasonal /akibatcorona virus.Fatah.S.16-maret 2020.7.05 Wib.
} 


\section{Peran Media Teknologi Pendidikan Pada Kegiatan Belajar Mengajar Di}

\section{Tengah Pandemik Covid-19}

Namun, ada juga sebagian masyarakat bersikap cuek atau acuh- tak acuh terhadap Virus ini dan tidak disiplin mengikuti arahan pemerintah untuk berdiam diri di rumah. Peristiwa virus Corona yang menggemparkan dunia ini, bahkan disebut beberapa orang sebagai perang dunia melawan virus. Saat-saat seperti ini benarbenar mengajarkan tentang arti kemanusiaan. Kemanusiaan sejati melampaui batas-batas manusia yang terkotak-kotak, baik suku, ras, agama dan latar belakang. Semoga dunia belajar dari peristiwa ini, dan ependemic dari covid- 19 ini cepat bisa teratasi.

\section{Dampak-Dampak yang ditimbulkan oleh Covid-19 di Indonesia Terhadap Kegiatan Belajar Mengajar \\ 1. Dampak Covid-19 bagi pendidikan secara umum}

Penyebab COVID-19 tidak hanya berdampak di bidang kesehatan dan ekonomi global. Tetapi berdampak pada semua sektor, terlebih pada sektor pendidikan. Oleh karenanya, perlu dilakukan langkah antisipatif oleh setiap satuan pendidikan di tingkat daerah mengingat banyaknya agenda penting, seperti ujian nasional, dan seleksi masuk perguruan tinggi. United Nations Educational, Scientific and Cultural Organization (UNESCO) mencatat, COVID-19 berdampak pada pendidikan sekitar 290,5 juta pelajar di seluruh dunia. Direktur Jenderal UNESCO Audrey Azoulay mengatakan, anak-anak dan remaja yang kurang beruntung adalah mereka yang cenderung paling terdampak dengan adanya penutupan sekolah. Meskipun penutupan sekolah sementara sebagai akibat dari masalah kesehatan dan krisis lain bukan hal yang baru, namun, skala global dan kecepatan gangguan pendidikan saat ini tidak tertandingi dan jika diperpanjang, dapat mengancam hak atas pendidikan" ${ }^{6}$ Seperti dikutip dari laman resmi UNESCO, bahwa UNESCO mencatat, hingga 4 Maret 2020 terdapat 22 negara yang telah mengumumkan penutupan sekolah sementara demi mencegah penyebaran COVID-19, sebelumnya, hanya Tiongkok yang menerapkan kebijakan tersebut. Mereka mengungkapkan sudah ada sembilan negara yang menerapkan penutupan sekolah secara lokal untuk mencegah penyebaran virus corona ini. Apabila ini diperluas menjadi kebijakan nasional, 180 juta anak dan remaja pelajar lain akan terdampak. UNESCO menyatakan bahwa meski bersifat sementara, penutupan sekolah berdampak pada berkurangnya waktu pengajaran dan bisa berdampak pada prestasi. Selain itu, kerugian lain yang akan muncul adalah rasa tidak nyaman pada keluarga serta turunnya produktivitas ekonomi karena orangtua harus mengurus anak sekaligus bekerja. Maka dari itu, UNESCO mendukung implementasi program pembelajaran jarak jauh dalam skala besar serta merekomendasikan aplikasi dan platform pendidikan yang terguna serta dapat digunakan sekolah dan guru untuk menjangkau peserta didik dari jarak jauh.

Pemerintah pusat hingga daerah memberikan kebijakan untuk meliburkan seluruh lembaga pendidikan. Hal ini dilakukan sebagai upaya mencegah meluasnya penularan virus corona. Kebijakan ini diharapkan dengan seluruh lembaga pendidikan tidak melaksanakan aktivitas seperti biasanya, sehingga dapat meminimalisir menyebarnya penyakit covid -19 ini. Hal serupa juga sudah dilakukan oleh berbagai negara yang

\footnotetext{
${ }^{6}$ Audrey Azoulay, UNESCO. Dirjen unesco
} Director-General of the United Nations Educational, Scientific and Cultural Organization (UNESCO) di lihat 22 maret 2020. 


\section{Peran Media Teknologi Pendidikan Pada Kegiatan Belajar Mengajar Di Tengah Pandemik Covid-19}

terpapar penyakit covid-19 ini. Kebijakan lockdown atau karantina dilakukan sebagai upaya mengurangi interaksi banyak orang yang dapat memberi akses pada penyebaran virus corona. Penyebaran virus corona ini pada awalnya sangat berdampak pada dunia ekonomi yang mulai lesu, tetapi kini dampaknya dirasakan juga oleh dunia pendidikan. Kebijakan yang diambil oleh banyak negara termasuk Indonesia dengan meliburkan seluruh aktivitas pendidikan, membuat pemerintah dan lembaga terkait harus menghadirkan alternatif proses pendidikan bagi peserta didik maupun mahasiswa yang tidak bisa melaksanakan proses pendidikan pada lembaga pendidikan, Berdasarkan data yang diperoleh dari UNESCO, saat ini total ada 39 negara yang menerapkan penutupan sekolah dengan total jumlah pelajar yang terpengaruh mencapai 421.388.462 anak. China sejauh ini memiliki jumlah pelajar yang paling banyak terpengaruh karena virus corona yaitu sekitar lebih dari 233 juta siswa. Sedangkan negara lainnya, hingga 13 Maret 2020 terdapat 61 negara di Afrika, Asia, Eropa, Timur Tengah, Amerika Utara dan Amerika Selatan yang telah mengumumkan atau menerapkan pembatasan pembelajaran sekolah sampai universitas. UNESCO menyediakan dukungan langsung ke negara-negara, termasuk solusi untuk pembelajaran jarak jauh yang inklusif. Audrey Azoulay, 2020, dalam sebuah pernyataan menegaskan, UNESCO bersama setiap negara-negara bekerja sama untuk memastikan kesinambungan pembelajaran bagi semua, terutama anak-anak dan remaja yang kurang beruntung yang cenderung paling terpukul oleh penutupan sekolah. Kebijakan menutup sekolah di negaranegara tersebut, berdampak pada hampir 421,4 juta anak-anak dan remaja di dunia. Negara yang terkena dampak Covid-19 menempatkan respons nasional dalam bentuk platform pembelajaran dan perangkat lain seperti pembelajaran jarak jauh. Dalam situs UNESCO dikemukakan bahwa pandemi corona ini mengancam 577 juta pelajar di dunia. Total jumlah pelajar yang berpotensi berisiko dari pendidikan pra-sekolah dasar hingga menengah atas adalah 577.305.660. Sedangkan Jumlah pelajar yang berpotensi berisiko dari pendidikan tinggi sebanyak 86.034.287 orang. ${ }^{7}$

Saat ini di Indonesia, beberapa kampus mulai menerapkan kebijakan kegiatan belajar mengajar dari jarak jauh atau pembelajaran secara online. Hal ini sebenarnya tidak masalah bagi perguruan tinggi yang sudah memiliki sistem akademik berbasis daring. Namun akan menjadi masalah bagi perguruan tinggi yang belum memiliki sistem akademik berbasis daring, apalagi kalau sumber daya para pengajar belum begitu memahami sistem pembelajaran dengan mengunakan aplikasi daring. Belum lagi masalah koneksi Internet belum maksimal bagus pada setiap kampus ataupun sekolahsekolah dan tidak semua siswa mempunyai smartphone dan notebook atau computer yang terkoneksi dengan internet. Ini menjadi salah satu kendala yang dihadapi oleh pemerintah untuk menerapkan pembelajaran secara daring. Kemendikbud berdasarkan keterangan secara resminya, siap dengan semua skenario termasuk penerapan bekerja bersama-sama untuk mendorong pembelajaran secara daring (dalam jaringan) untuk para siswa dan mahasiswa, Hal ini sebagai upaya agar siswa tetap belajar di rumah, Kementerian Pendidikan dan Kebudayaan (Kemendikbud) menyiapkan sejumlah dukungan untuk memperlancar proses

${ }^{7}$ Audrey Azoulay, UNESCO. Dirjen unesco Director-General of the United Nations Educational, Scientific and Cultural Organization (UNESCO) di lihat 22 maret 2020. 


\section{Peran Media Teknologi Pendidikan Pada Kegiatan Belajar Mengajar Di Tengah Pandemik Covid-19}

tersebut. Kemendikbud sendiri mengembangkan aplikasi pembelajaran jarak jauh berbasis portal dan android Rumah Belajar. Portal Rumah Belajar dapat diakses di belajar.kemdikbud.go.id. Beberapa fitur unggulan yang dapat diakses oleh peserta didik dan guru di antaranya Sumber Belajar, Kelas Digital, Laboratorium Maya, dan Bank Soal. Rumah Belajar dapat dimanfaatkan oleh siswa dan guru Pendidikan Anak Usia Dini (PAUD), Sekolah Dasar (SD), Sekolah Menengah Pertama (SMP), Sekolah Menengah Atas/Kejuruan (SMA/SMK) sederajat digunakan secara gratis. Kemendikbud turut menggandeng tujuh platform belajar online yakni Kelas Pintar, Sekolahmu, Zenius, Quipper, Google Indonesia dan Microsoft. Setiap platform akan memberikan fasilitas yang dapat diakses secara umum dan gratis. Platform belajar online ini bisa diakses oleh peserta didik dan guru untuk menambah sumber pembelajaran. $^{8}$

Pandemi corona ini memang sebuah ujian yang berat bagi seluruh bangsa, menguji kemampuan semua bangsa untuk dapat mengambil hikmah dengan terus berupaya dan berikhtiar mencari solusi pada setiap masalah yang ada. Sebagai bangsa yang besar, Indonesia harus mampu melalui segala masalah yang ada. Hal ini dibuktikan dengan Indonesia siap dengan segala kemungkinan, dengan lahirnya teknologi-teknologi karya anak bangsa untuk memberikan layanan pendidikan secara daring. Dengan harapan bangsa ini menjadi bangsa yang teruji dan layak untuk menjadi bangsa yang hebat pada masa yang akan datang.

\section{Langkah Strategis Penanggulangan Dampak Covid-19 Terhadap Kegiatan Belajar Mengajar}

Di Indonesia, penderita positif corona juga terus bertambah. Dengan bertambahnya penderita ini, maka telah memberikan efek negatif yang lebih besar terhadap sektor pendidikan. Untuk itu meredam dampaknya, maka dibutuhkan langkah-langkah strategis. Hal ini perlu dilakukan oleh pemerintah cepat dan tepat. Hal pertama yang perlu dilakukan adalah memberikan edukasi kepada para siswa dan praktisi pendidikan. Ini bisa dilakukan dengan sosialisasi secara intensif oleh dinas kesehatan tentang virus corona itu sendiri, baik dari aspek pencegahannya maupun cara menyikapinya. Dengan wawasan ini diharapkan dapat mengurangi efek kekhawatiran berlebih yang dapat menyebabkan dampak traumatis pada diri siswa dan tentu juga para gurunya. Langkah kedua adalah perlu menyiapkan tim khusus dari para psikolog untuk melakukan pendampingan terhadap para siswa baik secara kolektif maupun individu, khususnya terhadap sekolahsekolah yang berada di wilayah terdampak virus. Seperti wilayah DKI yang terbanyak terdeteksi virus Corona. Siswa yang terkena covid-19 tetapi dinyatakan sembuh diharapkan dapat menghadirkan pendampingan sehingga dapat meringankan beban psikologis mereka serta menguatkan kembali semangat belajarnya.

Adapun untuk terhambatnya proses pendidikan karena penutupan dan penundaan waktu belajar, maka perlu disiapkan solusi kongkret pula. Salah satu yang bisa dilakukan adalah dengan sistem pembalajaran jarak jauh dengan memanfaat teknologi yang ada. Sebab jika tidak, maka ini akan memberikan dampak negatif terhadap perkembangan

\footnotetext{
${ }^{8}$ Nadiem makarim. (Kompasiana, 2020). 15/03/2020). Dilihat 21- maret 2020.
} 


\section{Peran Media Teknologi Pendidikan Pada Kegiatan Belajar Mengajar Di}

\section{Tengah Pandemik Covid-19}

kematangan hasil dan pencapaian dari proses pendidikan ${ }^{9}$

\section{Kebijakan Kementerian Pendidikan dan kebudayaan RI Terhadap wabah Virus Corona dalam kegiatan Belajar Mengajar (KBM)}

Sekolah adalah tempat terjadinya interaksi dan proses belajar mengajar di dalam kelas. Di sana tempat siswa-siswi memperoleh ilmu pengetahuan. Proses pembelajaran akan lebih berhasil bila bahan pembelajaran tersebut dikemas sedemikian baik, sehingga dapat menarik perhatian semua siswa. Selama ini sekolah adalah rumah kedua bagi siswa, dimana guru adalah orang tua yang kedua bagi semua murid ${ }^{10}$ nyaman bagi semua siswa. Tetapi siapa sangka sekolah yang tadinya adalah rumah kedua bagi siswa, tempat yang nyaman tetapi sekarang dianggap tidak aman lagi bagi seluruh warga sekolah. Hal ini disebabkan karena Virus Corona yang semakin menyebar. Sesuai dengan kebijakan dari pemerintah pusat Republik Indonesia, yang mana tujuannya untuk mengantisipasi persebaran Virus Corona, semua warga harus mengurangi aktivitas diluar rumah akibat dampak yang ditimbulkan persebaran Virus Corona. Penyebaran Virus Corona juga menyebabkan aktivitas pembelajaran di sekolah (di dalam kelas) dan di kampus sebagian wilayah Indonesia terpaksa dihentikan selama beberapa hari ke depan dan belum tau entah kapan keadaan kembali normal seperti biasa. Para siswasiswi dan juga Mahasiswa dirumahkan

\footnotetext{
${ }^{9}$ Muhammad Rajab, Director of Ma'had and Islamic Studies Tazkia International Islamic Boarding School, Malang. Seminar, 2020.

${ }^{10}$ Yuli Hendarti, Optimalisasi Pembelajaran Berbasis Online Selama Covid-19 ttps: //www.rakyatpos.com/optimalisasi. (searching, 22 Maret 2020).
}

untuk belajar mandiri (belajar secara online).

Menteri Pendidikan dan Kebudayaan (Mendikbud) Nadiem Anwar Makarim mendukung kebijakan pemerintah daerah (Pemda) yang meliburkan sekolah dan menunda pelaksanaan ujian Nasional (UN). Hal itu sebagai langkah mencegah penyebaran virus corona atau coronavirus disease 2019 (Covid-19). Dampak penyebaran Covid-19 akan berbeda dari satu wilayah ke wilayah lainnya. Kementerian Pendidikan dan Kebudayaan siap dukung kebijakan yang diambil Pemda. Keamanan dan keselamatan peserta didik serta guru dan tenaga kependidikan itu yang utama (Kompasiana, 2020). Kebijakan pemerintah pusat yang mendukung pemerintah daerah untuk merumahkan siswa beberapa hari ke depan untuk belajar dirumah, disambut baik oleh pemerintah daerah, misalnya pemerintah DKI -Jakarta memberlakukan belajar di rumah pada semua tingkatan mulai dari tingkat SD dan SMP, SMA. Bahkan sebelum ditetapkan secara resmi permberlakuan belajar dirumah sudah ada beberapa kampus universitas telah melaksanakan pembelajaran secara Eleraning atau Daring. Meskipun kegiatan pembelajaran tidak dilaksanakan secara tatap muka di dalam kelas, harapannya seluruh siswa dan mahasiswa dapat belajar mandiri di rumah secara online, agar selama dirumahkan seluruh siswa atau mahasiswa tidak ketinggalan pelajaran.

Kemendikbud mengimbau tiap unit satuan pendidikan untuk melaporkan ke dinas pendidikan, dinas kesehatan ataupun Lembaga Layanan Pendidikan Tinggi bilamana terjadi ketidakhadiran secara massal para siswa. Lalu berkonsultasi dengan dinas pendidikan atau LL Dikti jika tingkat ketidakhadiran mengganggu proses belajar mengajar, sehingga akan dicari cara penyelesaiannya. Dalam surat edaran kemendikbud menjelaskan mekanisme 


\section{Peran Media Teknologi Pendidikan Pada Kegiatan Belajar Mengajar Di Tengah Pandemik Covid-19}

bagi siswa maupun orang tua siswa yang berpergian di negara-negara yang terjangkit, maka diminta untuk meliburkan diri selama beberapa hari kedepan. Siswasiswi wajib untuk setiap saat memantau kondisi kesehatannya di rumah, tetapi aktif juga mendeteksi kesehatan dirinya, baik ke dokter atau ke pusat layanan kesehatan. Jadi, tidak hanya di rumah, namun aktif memeriksakan kesehatan.

Untuk mengantisipasi penyebaran Virus Corona di semua sekolah, diimbau untuk mengaktifkan peran Usaha Kesehatan Sekolah (UKS) atau unit layanan kesehatan di perguruan tinggi dengan cara berkoordinasi dengan fasilitas pelayanan kesehatan setempat dalam rangka pencegahan penyebaran Covid-19. Usaha kecil yang dapat dilakukan sekolah adalah agar meningkatkan kebersihan lingkungan sekolah, semua warga sekolah mencuci tangan lebih sering, tidak kontak langsung dengan sesama siswa misalnya bersalaman, berpelukan, dan lain-lain. Bila ada yang terindikasi terkena Virus Covid19 agar segera melakukan komunikasi dengan Dinas Kesehatan, Dinas Pendidikan dan/atau Lembaga Layanan Pendidikan Tinggi setempat untuk mengetahui apakah Dinas Kesehatan telah memiliki semacam rencana atau persiapan dalam menghadapi Covid-19. Selain itu, pihak sekolah juga harus memastikan ketersediaan sarana untuk cuci tangan pakai sabun (CTPS) dan alat pembersih sekali pakai (tisu) di berbagai lokasi strategis di satuan pendidikan. Selain itu, pastikan warga satuan pendidikan menggunakan saranan CTPS (minimal 20 detik) dan pengering tangan sekali pakai sebagaimana mestinya, dan perilaku hidup bersih sehat (PHBS) lainnya tetap harus konsisten dilaksanakan ${ }^{11}$

\section{${ }^{11}$ Yuli Hendarti, Guru SMA Negeri 1} Pemali, Kab. Bangka, Bangka BelitungMedia online,
Jika kita melihat kemajuan teknologi pada masa kini, memang pembelajaran tidak hanya dilakukan di dalam kelas saja, dapat juga dilaksanakan secara Online. Guru sebagai pendidik harus bijaksana dalam mengambil langkah yang tepat untuk melanjutkan pembelajaran meskipun tidak dilaksanakan di dalam kelas. Hal ini mengingat situasi negara yang sekarang dilanda Virus Covid-19. Berdasarkan Undang-Undang Nomor 14 Tahun 2005 tentang guru dan dosen, bahwa dalam melaksanakan profesinya guru berkewajiban meningkatkan dan mengembangkan kualifikasi akademis dan kompetensi secara berkelanjutan sejalan dengan perkembangan ilmu pengetahuan dan teknologi, guru harus dapat menghadirkan atmosfer pembelajaran yang berkesan dan bermakna. Dalam tataran ideal, Guru mampu bersinergi dalam mengembangkan materi ajar menjadi media pembelajaran online yang sesuai dengan karakteristik siswa. Pengembangan materi ajar yang menarik menjadi sebuah tuntutan agar proses pembelajaran tidak berlangsung membosankan. Dalam hal ini, kreativitas dan inovasi Guru mengemas materi secara komunikatif menjadi penentu keberhasilan pembelajaran online. Dengan memanfaatkan sistem pembelajaran Online sangat dimungkinkan untuk mengemas materi ajar dalam format digital interaktif.

Pemanfaatan pembelajaran sistem online dalam dimensi pendidikan tidak dapat terelakkan. Faktanya tidak sedikit siswa yang betah berjam-jam dengan gadgetnya, misalnya: laptop, PC tablet, atau smartphone mereka. Dengan mengakses internet mereka dapat mencari beragam informasi dan pengetahuan yang diinginkan atau sekadar menunjukkan eksistensinya melalui media sosial. Fenomena ini menjadi tantangan sekaligus peluang bagi guru untuk kreatif mengembangkan metode pembelajaran yang menarik, inovatif dan menyenangkan. 


\section{Peran Media Teknologi Pendidikan Pada Kegiatan Belajar Mengajar Di Tengah Pandemik Covid-19}

Pembelajaran inovatif yang memanfaatan basis online sebagai medianya bisa diwujudkan dalam bentuk pembelajaran berbasis multimedia interaktif dan media pembelajaran berbasis blogpribadi oleh guru. Proses pembelajaran tidak melulu tersekat oleh ruang dan waktu. Ilmu pengetahuan tidak mutlak hanya di dapat melalui lisan seorang guru, tetapi juga bisa diperoleh melalui berbagai referensi misalnya internet. Pada sisi lain, gaya mengajar guru pun mengalami transformasi dari model ceramah konvensional menjadi presentasi berbasis multimedia. Terlebih dalam kurikulum 2013 menuntut guru secara masif piawai menggunakan TIK sebagai penunjang proses pembelajaran. Menurut (Reeves, 1998), dalam proses pembelajaran terdapat dua pendekatan pokok dalam penggunaan TIK, yaitu siswa dapat belajar 'dari' dan 'dengan' TIK. Belajar 'dari' TIK dilakukan. Seperti dalam penggunaan computer-based instruction (tutorial) atau integrated learning system. Sedangkan belajar 'dengan' TIK adalah menggunakannya sebagai cognitive tools (alat bantu pembelajaran kognitif) dan lingkungan pembelajaran konstruktivis (constructivist learning environments). ${ }^{12}$

Dengan menggunakan sistem pembelajaran Online, idealnya dapat mengubah wajah pendidikan ke arah yang lebih baik, lebih menyenangkan, dan lebih efektif bagi siswa. Berdasarkan kondisi negara kita saat ini yang sedang dilanda Virus Covid-19, peranan pembelajaran berbasis online sebagai penunjang proses pembelajaran menjadi sangat signifikan dan diperlukan. Lebih-lebih pada era global sekarang, transformasi berjalan sangat cepat. Realitanya siswa bahkan

\footnotetext{
${ }^{12}$ Reeves, T.C. 1998. The impact of media and technology in schools. A research report prepared for the Bertelsmann Foundation. Amerika Serikat: University of Georgia.
}

dapat lebih mudah beradaptasi dengan teknologi baru dan perubahan-perubahan yang ada pada masa kini. Penerapan pembelajaran berbasis online untuk proses belajar mengajar memiliki dua tantangan besar yaitu: (1) penerapan pembelajaran berbasis on line sebagai 'alternatif sulit bagi siswa'; dan (2) penerapan berbasis online untuk menghasilkan siswa berpengetahuan (knowladge-based student), yaitu mengambil keuntungan dari berbasis online untuk mengembangkan diri secara terus menerus (long life learning) dan meningkatkan produktivitasnya.

Pembelajaran berbasis online ini diharapkan memberikan dampak positif bagi siswa dan kemajuan pendidikan kita. Dalam hal ini guru juga mengharapkan peran serta dan kepedulian orang tua di rumah agar mengimbau anak-anak mereka untuk belajar di rumah, menggunakan fasilitas dan sistem pembelajaran berbasis online yang sudah ditetapkan oleh pemerintah melalui Dinas Pendidikan selama Covid-19 ini melanda.

\section{E. Kesimpulan}

Pandemi Virus corona yang dapat menyerang pernapasan manusia, virus ini sangat berbahaya dan sampai saat ini belum ditemukan obat atau faksinya. Adapun negara yang laing parah setelah cina adalah, negara italia, Iran, korea selatan, inggris, german, dan diikuti negara-negara yang lainya termasuk Indonesia. Antisipasi yang paling ampuh untuk meredam virus corona ini adalah menghindari dari keramaian (stay at home), menjaga kebersihan dan menjaga daya tahan tubuh. Dampak yang dialami oleh setiap negara adalah di bidang ekonomi, sosial budaya, dan tidak ketinggalan pula di bidang pendidikan, sekolah, kampus, semua diliburkan dan diganti pembelajaran dari rumah dengan menggunakan media teknologi pembelajaran seperti menggunakan Daring 


\section{Peran Media Teknologi Pendidikan Pada Kegiatan Belajar Mengajar Di}

Tengah Pandemik Covid-19

atau disebut dengan E-learning. Pembelajaran mengunakan E-learning membawa kemajuan dan inovasi pada pendidikan di Indonesia karena hampir $75 \%$ siswa siswi melakukan online learning secara bersamaan selama terjadinya pendemi covid-19. Kendala pelaksanakan E-Learning ini pasti ada, misalnya, tidak terpenuhi jaringan internet, tidak terbiasanya siswa, guru, bahkan orang tua sebagi pendamping belajar dirumah untuk melakukan pembelajaran secara Online. Ini tentunya hal yang biasa, karena belum menjadi suatu kebiasaan bagi siswa dan guru dalam melaksanakan KBM butuh proses kedepanya agar mendapat hasil pembelajaran yang lebih baik. Berbagai upaya dilakukan untuk menanggulangi pandemi, antara lain dengan pembatasan interaksi antar anggota masyarakat. Kegiatan pembatasan meliputi: peliburan sekolah dan tempat kerja, pembatasan kegiatan keagamaan, dan pembatasan kegiatan di tempat dan fasilitas umum sosial berskala besar (psbb) merupakan bagian dari respon kedaruratan dan bertujuan mencegah meluasnya penyebaran penyakit. Terjadinya dari peristiwa ini banyak hikmah yang dapat dipetik, salah satunya adalah selama ini kita sudah tidak memperhatikan lingkungan kita, kurang menjaga kebersihan, jauh dari perintah agama yang seharusnya kita amalkan dalam kehidupan sehari-hari, jauh dari keluarga dan kita lebih banyak mengurusi hal-hal keduniwian saja. Hal inilah yang menjadi suatu teguran dari yang Maha Kuasa kepada umat manusia yang ada di dunia ini.

\section{DAFTAR PUSTAKA}

M. Ngalim P.1997.Psikologi Pendidikan. Bandung. Penerbit. Remaja Rosda Karya. ISBN 979-514-036-1. Edisi pertama. cetakan ke. XXVII.
Purwadinata. 1997. Psikologi Pendidikan dengan Pendidikan Baru. PT Remaja Rosdakarya: Bandung.

Kennedy, Paul.1995. Menyiapkan Diri menghadapi Abad ke-21. Yayasan Obor: Jakarta.

Paul Suparno. 1997. Teori perkembangan kognitif. Public. Kanisius, Jakarta.

Paul Suparno.1991. Teori Perkembangan Kognitif Jean Piaget. Yogyakarta: Penerbit Kanisius. Solso.

D.Hardianto.2005. Media Pendidikan sebagaisarana pembelajaran efektif, Jakarta.

Reeves, T.C. 1998. The impact of media and technology in schools. A research

report prepared for the Bertelsmann

Foundation. Amerika Serikat: University of Georgia.

Yuli Hendarti, Optimalisasi Pembelajaran Berbasis Online Selama Covid-19 ttps://www.rakyatpos.com/optimalisa si. (searching, 22 Maret 2020).

https://anteroaceh.com/news/corona-dandampak-sosial/index.html.

Yugi Prayanto, dalam acara Outlook Perikanan 2020 di Jakarta, Rabu (26/2. 2020. (searching tanggal 22. Maret 2020.)

Fathan, Anggota komisi V. DPR RI, berbicara masalah penangulangan Covid-19. (Dilihat 20 MARET 2020.

Audrey Azoulay, UNESCO. Dirjen unesco Director-General of the United Nations Educational, Scientific and Cultural Organization (UNESCO) di lihat 22 maret 2020.

Uffie, Direktur kelas Pinter, aplikasi pembelajaran -e-Learning. 2020.

Dedy Afrianto, Seminar antisipasi Dampak Covid-19 di Sektor PendidikanPandemi Covid-19 yang disebabkan virus korona baru memberikan dampak pada sektor pendidikan. 2020. 
https://kompas.id/baca/riset/ (dilihat pada tanggal $20 / 03 / 2020$.

https://www.rakyatpos.com/dampakpenyebaran-virus-corona-terhadappembelajaran-di-sekolah.html/

Teori Pembelajaran", (13 september 2016) http://joegolan.wordpress.co.i d

Lestari Dewi, (13 "Teori-teori Belajar dan Pembelajaran", $\quad$ http://biologilestari.blogspot.co.id

M Razi Rahman,https://today.line.me/i ntaranews.com dilihat 20 maret 2020.

Muhammad Rajab Director of Ma'had and Islamic Studies Tazkia International Islamic Boarding School, Malang. Seminar, 2020.

Yuli Hendarti, Guru SMA Negeri 1 Pemali, Kab. Bangka, Bangka BelitungMedia online,

Nadiem makarim. (Kompasiana, 2020). 15/03/2020). Dilihat 21- maret 2020.

serambinews.com dengan judul Pengaruh Corona terhadap Kehidupan Sosial Masyarakat,

https://aceh.tribunnews.com/2020/03/21/pe ngaruh-corona-terhadap-kehidupansosial-masyarakat.

Sapto Waluyo (Center for Indonesian Reform) https://www.suara.com/

Webside Pemda DK

http://corona.jakarta.go.id.
Haryono. 2017. Teknologi Pendidikan dan Pembelajaran Abad 21. Makalah Seminar Nasional Teknologi Pendidikan dengan Tema "Inovasi Pendidikan di Era Cyber dan Peran Teknologi

Pendidikan/Pembelajarann dalam Meningkatkan Mutu Pendidikan di Indonesia" di Banjarmasin. Pascasarjana Universitas Negeri Semarang. Ristekdikti. 2018. Mempersiapkan SDM Indonesia di Era Revolusi Industri 4.0. Kementerian Riset, Teknologi dan Pendidikan Tinggi.

Undang-Undang Nomor 59 berdasarkan Undang-undang Nomor 6 Tahun 2018 tentang Kekarantinaan Kesehatan.

Fatah .S. Media online, http://www.alinea.id./nasional/akibat coronavirus.diambil 16-maret 2020. Jam 7-05 Wib. 
Peran Media Teknologi Pendidikan Pada Kegiatan Belajar Mengajar Di Tengah Pandemik Covid-19 